\title{
Exploring the reasons for perennial attacks on churches in Nigeria through the victims' perspective
}

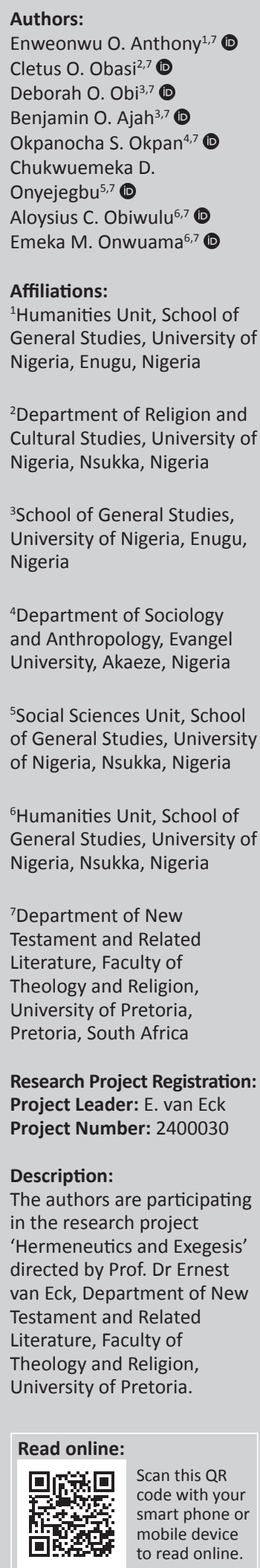

Although there are several provisions within the Nigerian legal framework that, however, address the issue of church attack, the state capacity to implement effective constitutional sanctioning on perpetrators of this heinous crime has always been found wanting or completely absent, leading to countless religious attacks on churches with seeming state consent. This study employs semi-structured interviews to draw data from affected families from Benue and Enugu States, Nigeria. The article explored their experiences. The study participants were recruited through snowball sampling technique, and data were analysed thematically. The respondents stated that church killings or killing of Christians is rising because of the fact that perpetrators stand lower risk of detection and apprehension than other crimes. Also respondents interrogated that justification for the crime is land acquisition and religious intolerance. On the persistence of the challenge, all the 13 respondents stated that the crime seems to have state approval that has made it seemly impossible to tackle. The article calls for continuous inter-religious dialogue and intentional governmental responsibility in protecting lives of all persons living within the geographical enclave of Nigeria which is necessary for the common good. Closer understanding of other faiths and religions will help build bridges of peace and tolerance. The article also calls for the need to promote African traditional values, such as the value of sacredness of life, human respect and good neighbourliness.

Contribution: This study initiated the discussions that will help the public understand the reason for continuous church attacks in Nigeria, what church crime connotes in the Nigerian context and its uniqueness from other crimes. These discussions sit quite well within the transdisciplinary religious perspective of this journal.

Keywords: Christianity; sanctuary killings; victims; church; violent crime.

\section{Introduction}

The church is a sacred place where the Christians worship. Christianity is one of the oldest religions in the world (Egbegi, Ajah \& Ogbonnaya 2018; Okpa, Ajah \& Okunola 2018). Crimes in churches are growing rampantly across local villages and towns in Nigeria. The news outlets report them, scholars tell their stories in writing and people talk about their personal experiences in hushed voices in the streets. Committing crimes in churches is not new, and crimes had always been committed in churches for almost as long as churches existed (Ajah 2018; Ajah \& Nweke 2017; Essays UK 2013; Nnam et al. 2019; Nweke \& Ajah 2017; Nwune et al. 2018; Okpa et al. 2018; Suleiman 2016). What, however, necessitates this study is the recent unprecedented proliferation of crimes on church premises and against Christians in Nigeria. In the sequence of things, crimes committed on church premises are different from every other crime perpetrated outside church premises; such unique differences are angled from social viewpoints, religious sanctity, sectarian genocide and retaliatory complications. The attack on churches has been far-reaching and comprehensive, being compounded with insufficient scholarly studies on violence in church premises within Benue and Enugu States behoove the need for the article.

\section{Ele (2001) wrote that:}

The history of Christianity in Nigeria today is replete with dramatic chapters of the massacres of Christ's disciples by fanatical Muslims and other persons given to such anti-nature trait of killing innocent people. Too many a Christian, especially in Nigeria have paid the tribute of blood while others are still under the

Corresponding author: Benjamin Ajah, okorie.ajah@unn.edu.ng

Dates: Received: 18 June 2020 | Accepted: 22 Dec. 2020 | Published: 29 Mar. 2021

How to cite this article: Anthony, E.O., Obasi, C.O., Obi, D.O., Ajah, B.O., Okpan, O.S., Onyejegbu, C.D. et al., 2021, 'Exploring the reasons for perennial attacks on churches in Nigeria through the victims' perspective', HTS Teologiese Studies/Theological Studies $77(1)$, a6207. https://doi.org/10.4102/hts.v77i1.6207

Copyright: (C) 2021. The Authors. Licensee: AOSIS. This work is licensed under the Creative Commons Attribution License.

Note: Special Collection: Africa Platform for NT Scholars, sub-edited by Ernest van Eck (University of Pretoria). 
yoke of persecution, the absence of religious freedom, shackles of violence and the threat of death. Some Christian sacred spaces have been committed to smoking ruins at any sudden eruption and the least provocation of ethnic/religious quarrel. (n.p.)

Further, Ele (2018) found that amongst other things, Islam has multidimensional approaches to ensure that Nigeria becomes an Islamic state. The researcher also discovered with some rude shocks that Islam identifies every nonMuslim as an infidel who is good only to be wasted by torture and gruesome death. This implies that peace is not guaranteed in the enterprise of cohabiting with adherents of Islam.

Instances abound of some gruelling attacks and killings. The 50 Christian deaths in March 2020 included the 13th and 14th March 2020 killings by the Jihadist herdsmen of seven Christian mourners in coordinated attacks in Guma L.G.A of Benue State. Amongst the slain Christians were one Chikwa, Taza Abuur and Tarnum Yanum. In 8 years, between 2011 and 2019, Benue State alone has lost over 600 churches and other Christian worship centres to Fulani herdsmen. One of the big worries is that most church crimes go unreported. Like other crimes that lead to the death of many Nigerian citizens, church crimes are also threats to national security (Longji 2015). From Northern to Southern Nigeria, Christians are daily afraid of worshipping at churches or forming any congregation for religious purposes. Their growing unwritten national norm is to avoid any gathering that is designated for worship, prayers or religious purposes. The fears are propelled by events and news of killings perpetrated by outsiders who invade churches and Christian communities, kill and disappear with impunity. In fact, there has been a steady influx of largely illiterate and religiously radicalised Northern Muslim youths into communities and cities in the Southeast and the South. As at December 2019, forests and bush lands of over 139 Igbo communities, towns and hamlets have been invaded by violent Fulani herdsmen. Some rural communities in the Igbo region including Enugu State have already become unsafe 'no-go areas' (Umeagbalasi 2020). Apart for attacking Christian settlement in the NorthCentral, Northeast and some parts of the Northwest, Jihadist herdsmen have also launched incessant attacks in the Southeast and South-south leading to death of no fewer than 200 Christians since June 2015. The killings were mostly recorded in Enugu, Anambra, Delta and Edo States. Individual cases in Enugu State abound. Revered Father Clement Ugwu abducted and killed on 14th March 2019. In the same vein, Revered Father Paul Offu abducted and killed on 01 August 2019. In September 2016, Revered Father Dim, Ezeokana and Chukwuemeka were abducted in Nsukka along Nkpologwu-Nimbo Road in Enugu State. Mamah et al. (2016) revealed that Fulani herdsmen in Enugu State attacked Ukpabi Nimbo in Uzo-Uwani Local Government Area on 25 April 2016, killing over 40 people. Survivors fled to neighbouring communities. Two days after the Ukpabi Nimbo attack, there was another attack by the Fulani herdsmen in Umuchigbo community in Enugu East Local Government Area of Enugu State.
Hence, the Federal Government of Nigeria, confirming this disturbing situation through the Minister for Information, Lai Mohammed, stated that (Daniel 2020a):

$[T]$ he terrorists were deliberately deploying the antics of attacking Christians and Churches in order to sow the seed of confusion between the two great religions ... They have started targeting Christians and Christian villages for a specific reason, which is to trigger a religious war and throw the nation into chaos. Apparently, they have realized how emotive and divisive religion can be, when exploited by unscrupulous persons. (n.p.)

Fulani extremists have upgraded their terror and extended the terror to South-Eastern and South-Western Nigeria (Agbu, Musa \& Zhema 2020).

In 2018, in a small village called Ukpor-Mbalom in Benue State, a group of armed men stormed a Catholic Church around 05:30 and killed 17 worshippers who came for morning Mass or devotion (Wantu 2018). Later, in February 2019, some Islamic herdsmen attacked a Catholic Parish in same Mbalom in Benue State and killed all worshippers in attendance for morning Mass or devotion, claiming that members of the Parish were responsible for converting hundreds of Moslems to Christianity (Chris 2019). A lot of other church killings happened between 2018 and 2019 besides these two, both in Benue and Enugu States. Instances abound, like the regular killing of Christians by Moslem locals in Jos (Morning Star News 2019) or the September 2018 burning of a pastor, his wife and three sons in their church building by a Moslem group in Plateau State (World Watch Monitor 2018). Each of these cases paints a summarised picture of common experiences in Nigerian churches. Nigeria is neither an Islamic nor a Christian country. It was amalgamated in 1914 and united as a country under a social contract of religious tolerance that is well underpinned by religious neutrality or 'freedom of religion' in her constitution. Each of these violent cases in churches goes against this foundation of contract and each is precipitated by various reasons. Whilst some of the perpetrators claim that Christians preach and convert Moslems to Christianity, others claim that Christians worship God in the wrong way, and the rest give their various reasons for violently attacking churches and killing worshippers on their holiest grounds (Okpa et al. 2018).

Scholars have been seeking causes of these crimes. Emeh (2011) argued that most crimes in Nigeria are caused by structural deviations. He points to corruption as one structural deviation that has fuelled poverty and gaps in wealth distribution - and stands as one key structural deviation fuelling violence across the nation. He also noted stagnancy in economic growth as second structural deviation. To Emeh, these two structural deviations subject citizens to intense economic difficulties that threaten their survival - and make them resort to violence. In other views, Okiro (2005) related proliferation of illegal arms to increasing ethno-religious crimes, arguing that the former causes the later. Both arguments could be valid when it 
concerns all forms of crimes in Nigeria. The challenge is that they are not specific to crimes committed on church premises in Nigeria and do not properly capture the specific relationships that concern church and crime. Not many scholars have researched on church crimes. Despite the increasing awareness of crimes in the learned community, there are still much to be performed on church crimes. Most literatures consider crimes in Nigeria as a general topic. This lack of specific scholarly study creates both research and knowledge gap on a case that has taken the lives of many Nigerians. This article is designed to fill this gap, to initiate the discussion and to help the public understand what church crime connotes in Nigerian context and its uniqueness from other crimes.

The study adopted a qualitative methodology approach for investigation and analysis of the issues presented herein. During data collection, interviews were conducted with 13 victims of the crime, who were selected through snowball sampling technique from Benue and Enugu States. Also, important information regarding attacks on churches was gathered through social immersion, documented articles and Internet sources. Newspapers and books relating to church killings were also consulted to investigate this research topic for theoretical analysis. At the data analysis stage, the information gathered was extracted by transcription and analysed through phenomenological narratives in relation to the theory adopted. The credibility and generalisability of this study are context-dependent. The interview data were used as the empirical input for data analysis.

\section{Background of religious crime in Nigeria}

It is no new thing to discuss crime and its existence in the Nigerian state. Many crimes have been committed in Nigeria from the period of the country's amalgamation till date. According to Union of Catholic Asian News (2020), 620 Christians have been killed in Nigeria this year (i.e. 2020) by Islamic militants, whilst Nigeria is ranked 12th on Open Doors' 2020 World Watch List of countries where Christians suffer the most persecution. Most of such crimes were ignited by the ethno-religious differences that surround the nation, with the Northerners being largely Moslems and Southerners largely Christians. The religious bipolarity is almost equivalent to assuming that Christianity is a Southern peoples' religion and Islam is a Northern peoples' religion. This has the implication that religion, which usually serves as a unifying factor for largely religiously homogeneous societies, does not hold same value for Nigeria, thus further exacerbating the effects of ethnic differences across the nation. To show the extent of the situation, the Donald Trump administration on Monday, 07th December 2020, designated Nigeria as a country of particular concern (CPC) for 'particularly severe' violations of religious freedom, a designation that opens it up to economic sanctions (The Guardian 2020).

\section{State of killings in Nigerian churches}

Data are lacking and most church crimes go unreported. Table 1 is a research effort by this article to gather lists of notable Christian killings in Nigeria within a specified period. This table contains statistics of notable crimes against Nigerian Christians between July 2006 and April 2018. This is a 12-year period.

Table 1 contains the statistics of recorded crimes that occurred in some churches and against Christians in Nigeria between February 2013 and March 2019. The church is a sacred institution where people obey the Christian laws and the

\begin{tabular}{|c|c|c|c|c|}
\hline $\mathrm{S} / \mathrm{N}$ & Date of committing crime & Place or state where crime is committed & $\begin{array}{l}\text { Names of offenders and victims or nature of attack } \\
\text { and consequences }\end{array}$ & Source \\
\hline 1 & February 2013 & Agatu LGA of Benue State & $\begin{array}{l}\text { Communities attacked by armed herdsmen in military } \\
\text { uniform, killing about } 500 \text { persons, several injured, } \\
\text { houses and food items burnt down. }\end{array}$ & (Agbu et al. 2020) \\
\hline 2 & 23rd March 2014 & Gbajimba, Guma LGA of Benue State & $\begin{array}{l}\text { Attack by armed Fulani herdsmen, killing } 25 \text { persons } \\
\text { and injuring } 50 \text {. }\end{array}$ & (Agbu et al. 2020) \\
\hline 3 & 24th May 2015 & $\begin{array}{l}\text { Ukura, Gafe, Per \& Tse-Gusa in Logo LGA } \\
\text { of Benue State }\end{array}$ & $\begin{array}{l}\text { Attacks on these communities by armed Fulani killing } \\
40 \text { persons, injuring many and burning of houses. }\end{array}$ & (Agbu et al. 2020) \\
\hline 4 & 25th April 2016 & Nimbo, Enugu State & $\begin{array}{l}\text { Attack on the community by armed Fulani herdsmen, } \\
\text { killing } 40 \text { persons, destruction of homes and farms. }\end{array}$ & (Agbu et al. 2020) \\
\hline 5 & September 2016 & Enugu State & $\begin{array}{l}\text { Revered Father Dim, Ezeokana and Chukwuemeka were } \\
\text { abducted in Nsukka }\end{array}$ & (Umeagbalasi 2020) \\
\hline 6 & 24th April 2018 & Ukpor-Mbalom, Benue State & $\begin{array}{l}\text { Armed herdsmen violently attacked and killed two } \\
\text { Catholic priests and } 17 \text { other worshipers at St. Ignatius } \\
\text { Quasi Parish. }\end{array}$ & (Refugee Documentation Centre 2018) \\
\hline 7 & 24th April 2018 & Benue State & $\begin{array}{l}\text { Revered Father Joseph Gor and Felix Tyolaha killed by } \\
\text { Jihadist herdsmen at St. Ignatius Quasi Parish } \\
\text { Ukpor-Mbalom }\end{array}$ & (Umeagbalasi 2020) \\
\hline 8 & 14th March 2019 & Enugu State & Revered Father Clement Ugwu abducted and killed. & (Umeagbalasi 2020) \\
\hline 9 & 8th August 2019 & Enugu State & $\begin{array}{l}\text { Revered Father Paul Offu of St. James the Greater } \\
\text { Parish in Ugbawka abducted and killed }\end{array}$ & (Nzwili 2019) \\
\hline 10 & February 2019 & Benue State & $\begin{array}{l}\text { Islamic herdsmen attacked and killed all worshippers } \\
\text { in attendance for morning Mass or devotion at Catholic } \\
\text { Parish. }\end{array}$ & (Agbu et al. 2020) \\
\hline 11 & 20th March 2019 & Enugu State & $\begin{array}{l}\text { Father Clement Ugwo of St. Mark Catholic Church, } \\
\text { Obinofia Ndiuno, was kidnapped and his decomposing } \\
\text { body was found in a bush a week later. }\end{array}$ & (Nzwili 2019) \\
\hline
\end{tabular}

LGA, local government area. 
TABLE 2: Oral interview.

\begin{tabular}{lllll}
\hline S/no & Informant's name & Age & Interview date & Interviewer \\
\hline 1 & Okechukwu T. & 31 & $04 / 09 / 19$ & Ajah, Okorie B. \\
2 & Usman Y. & 47 & $07 / 10 / 19$ & Okpan, Samuel \\
3 & Knor I. & 38 & $07 / 10 / 19$ & Okpan, Samuel \\
4 & Ogenyi M. & 40 & $04 / 09 / 19$ & Ajah, Okorie B. \\
5 & Magaji U. & 43 & $05 / 12 / 19$ & Olisa, Anthony \\
6 & Ibrahim G. & 34 & $05 / 12 / 19$ & Olisa, Anthony \\
7 & Oguama J. & 38 & $08 / 11 / 19$ & Obiwulu, Aloysius \\
8 & Kwerete S. & 33 & $17 / 11 / 19$ & Onwuama, Emeka \\
9 & Obinna D. & 51 & $17 / 11 / 19$ & Onwuama, Emeka \\
10 & Obum J. & 31 & $02 / 12 / 19$ & Obasi, Cletus \\
11 & Suswan Z. & 40 & $07 / 12 / 19$ & Onyejegbu, Dom \\
12 & Atese O. & 37 & $13 / 10 / 19$ & Okpan, Samuel \\
13 & Ezeh O. & 27 & $08 / 12 / 19$ & Obi, Deborah \\
\hline
\end{tabular}

Note: Pseudonyms were used for ethical reasons.

Nigerian constitutional laws - no one expects any kind of crime to be committed in a church or against harmless Christians. Though most of the crimes are perpetuated by outsiders, non-Christians or people from outside the church, the church members also commit crimes in their churches. From the table, it is clear that Fulani herdsmen account for most church killings in North Central and South Eastern Nigeria. Herdsmen terrorists account for most church crimes in Benue and Enugu States. In summary, events of the past few years have shown the spate of crimes committed against Christians which have assumed a debilitating proportion. The government whose duty is to protect the victims has performed little or nothing to arrest the situation.

\section{Theoretical framework}

The theoretical framework for this study is the systems theory of Ludwig Von Bertanlanffy propounded in 1968. This theory is an interdisciplinary approach that was based on the principles from biology, physics and engineering but later extended to numerous fields including sociology, psychology and philosophy. This theory views the society as a cohesive conglomeration of interdependent and interrelated parts that could be natural or manmade. According to Von Bertalanffy (1968), a system is a complex of interacting elements that are open to and interact with their environments. In addition, they can acquire qualitatively new properties through emergence, and thus they are in a continual evolution. Similarly, Beven (2006) noted that every system is delineated by its spatial and temporal boundaries, surrounded and influenced by its environment, described by its structure and purpose or nature and expressed in its functioning. In terms of its effects, a system can be more than the sum of its parts if it expresses synergy or emergent behaviour. Changing one part of the system usually affects other parts and the whole system, with predictable patterns of behaviour. For systems that are self-learning and selfadapting, the positive growth and adaptation depend upon how well the system is adjusted with its environment. Some systems function mainly to support other systems by aiding in the maintenance of the other systems to prevent failure.
Within the context of this article, the essence of the church is to ensure social and religious harmony and progress. This is enhanced through strong regulation by the government to ensure descent lifestyles. Thus, it is the obligatory responsibility of the government to protect the citizens through regulation of religious practices, provision of security and basic social amenities such as quality education, medical services, employment opportunities and so forth. Ironically, it seems that the government has failed to achieve this obligation that makes the church to be prone to deadly attacks.

\section{Ethical considerations}

Ethical clearance was obtained from the ethical committee of the University of Nigeria Teaching Hospital. NHREC/ 05/01/20088-FWA00002458-1R0000.

\section{Discussion of results}

\section{The dimension and nature of sanctuary crime}

Zenn (2017) observed that sanctuary killing, previously relatively unknown to Nigerians, has suddenly become domesticated. Bakeni (2019) and Cook (2012) had reported on the sudden rise in Christian sanctuary killings in Nigeria. In the opinions of the respondents, Christians-related killings in contemporary Nigeria are alarming. A 30-year-old respondent, who shared the view of a rising trend, explained that the reason is that church crime has lower risk of detection and apprehension than other crimes. Following respondents' choice of vocabularies, one concept emerged which defines the widespread of church crime. One of the respondents has said:

'Nwanne [my brother] ... blood dey run for our church today! [is haemorrhaging] to the grave because of wetin dey happen [what is happening] on daily attack of people in their churches.' (P1, 31 years old, interviewed on 04 September 2019)

The respondents rated church crime highest amongst all other crimes in Benue, only trailing behind armed robbery and banditry. This is in line with Umeagbalasi (2020), who reported several radical and violent crimes across Benue and Enugu States. This radicalism is seen more importantly in the areas of political, religious, social, economic and cultural life of Africa. In 17 June 2014, in a public event to examine the growing religious violence in sub-Saharan Africa, Ludovic Lado, one of the guests at the occasion, explained that the 'key impact on interreligious relations is that extremism from one religious group tends to breed extremism from other religious groups'. This is truly what is taking place in Africa. From Libya, Algeria, to Egypt, Mali, Sudan and Central African Republic, and from Nigeria, Somalia and Eritrea and other sub-Saharan African countries, the Al-Qaeda, Islamic State (ISIS), Boko Haram, the Jihadists, herdsmen terrorists, the Al-Shabab and their offshoots are terrorising the continent with extremely devastating attacks. The Nigerian army, for instance, has suffered casualties in the hands of Boko Haram and herdsmen (believed to be Fulani terrorists), in their effort to curtail the activities of these militants. The most overt manipulation of religion in most African politics is the use of the Sharia as an instrument to launch and implement Islamic 
religion against the will of non-Islamic believers who are also citizens (Ele 2018).

\section{The motives behind sanctuary killings}

In the words of Otu, Nnam and Uduka (2018), 'the motive behind a particular criminal conduct is of resounding relevance to researchers'. It is particularly germane in the study of church killings 'because it delves deeply into the direct and indirect, immediate and remote reasons why people engage in sustained attacks on churches'. From the respondents' accounts, and building upon the works of previous scholars who have carefully analysed the motives of other categories of crimes (see Egbegi et al. 2018; Emeh 2011; Evelyn 2018; Otu et al. 2018; Ugwuoke, Ajah \& Onyejegbu 2020; Ukwayi \& Okpa 2017), we constructed the following classification schemes consistent with controlling themes identified within the motives or reasons by our subjects:

1. Justification: Sad tale (e.g. mistreatment) and denial of injury.

2. Excuse: Appeal for defeasibility and scapegoating.

3. Apology.

\section{Justification}

Sad tale: According to Otu et al. (2018) and Pogrebin, Poole and Martinez (2012), 'sad tale depicts an account of number of disappointing experiences, conditions or circumstances which both collectively and cumulatively are used to explain and justify the actor's illegal behavior'. This is a kind of whipping up sentiment or what we refer to here borrowing from Sykes and Matza (1957) as 'appealing to higher authority'. Our subjects presented sad tales that invariably focused on the people pursuing them from a land legally given to them by the government.

\section{Mr. Usman has this to say:}

'The people are pursuing us out from a land which was legally given to us to graze. We reject the views of those who see us as trespassers on grazing lands.' (P2, 47 years old, interviewed on 07 October 2019)

Mr. Knor justifying his participation adds:

'Christian farmers see us as idol worshippers and we have been mistreated when we encounter local communities who are Christians.' (P3, 38 years old, interviewed on 07 October 2019)

Perhaps that is whilst Achunike (2008) presented a very inclusive argument which noted that:

$[T]$ he wrong perception of other people's religion or faith, wrong religious orientation, low literacy level of religious adherents, selfishness on the part of religious personalities, pervasive poverty, government involvement in religious matters, among others - breed ground for attacks in the church. (n.p.)

In many ways, Achunike's points cover most causes of church killings in Nigeria.

\section{Excuses}

Appeal for defeasibility: In the appeal for defeasibility, an offender tries to account for his/her behaviour by denying any intention to cause the admitted and proscribed harm, or by claiming a failure to foresee the rather unfortunate outcomes of one's act, or both. (see Egbegi et al. 2018; Otu et al. 2018)

Our respondents claim that they never intended to harm their victims nor expected that their victims would die in the manner they did.

A respondent has this to say:

'When I told her to abort the pregnancy, she was proving to be tough - not obeying my orders. I got angry. I sort of like let me make her understand that I was serious. I took her to a corner and gave her some beating and she collapsed. But I never took that serious. In fact, I thought she was just making it up. Unfortunately, she started showing signs of person struggling to breathe and all the other things are stories ... She died and my people started blaming me. I also felt bad!' (P8, 33 years old, interviewed on 17 November 2019)

Scapegoating: 'Scapegoating is all about shifting one's blameworthiness to others for one's untoward behaviour' (Otu et al. 2018):

Scapegoating becomes an excuse in church killings because of the contextual opportunity for the attacker to shift personal liability to the victim. The attacker contends that his or her action was as a result of the attitude and lifestyle of the victim. Scapegoating is saying that victims of church killings were the cause of their being victimised - a kind of victim precipitation. The attackers in the following example recognised the illegality of their behaviours by demeaning and denying responsibility, shifting the blame to the attacked victim. (n.p.)

A respondent notes:

'Our targets are people who kill our cattle and prevent us from moving freely without having any issue. We attacked them for killing our cattle and injuring one of our brothers.' (P2, 47 years old, interviewed on 07 October 2019)

Another respondent adds:

'This is caused by the failure of community members to understand us. They refused to give us adequate attention and it has been politicized and some narratives play into it.' (P5, 43 years old, interviewed on 05 December 2019)

\section{Implications of church killings}

Jamela (2018), Longji (2015), Otu et al. (2018) and Suleiman (2016) aver that the implication of church killings on the socio-economic and political growth of Nigeria is a very adverse one that obviously portends great danger for the country's development and investment agenda. Following from the answers, remarks and notes from our respondents, we have several implications of the killings that include socio-psychological and economic consequences.

\section{Socio-psychological}

This involves victims of church attacks suffering some degree of psychic disorder as a result of the uncertainties which confront 
them at (1) the initial stage of the attack (2) after the conclusion of the attack or drama. (Otu et al. 2018:n.p.)

Most times, victims and their relations continue to experience social withdrawal.

A 38-year-old victim in our study explained the predicament thus:

'Church attackers don [have] inflicted so much psychological pains on their victims and their relations. They treat them like say they no be human [subject them to inhuman treatment]. Victims go [will] cry out to his or her people and their people will cry out to law enforcement agencies. Relatives subject themselves to mental problem [torture] about wetin don happen [what has happened] to their persons [loved ones] and it is really too much!' (P7, 38 years old, interviewed on 08 November 2019)

\section{Economic}

'The economic implication of church killings is about the negative effects of church killings on the economic wellbeing of the people and social environment where it occurs' (Ajah, Nwokeoma \& Okpan 2017; Otu et al. 2018). 'Church attackers put fears in the mind of potential investors and active labour force, thereby scaring them away to seek sanctuary in a safe haven' (Ukwayi \& Okpa 2017; Ukwayi, Okpa \& Dike 2018). The argument here is that no right thinking person will invest his or her money where there is no security, as no labourer would like to work in a place that could not guarantee his or her safety and personal liberty.

A victim in our study explains:

Attacking churches don seriously [has adversely] affected the economy of Nigeria; E don [it has] scared away big [potential] investors and business persons away. True true, this don affect our development (Sincerely, this has retarded our development).' (P7, 38 years old, interviewed on 08 November 2019)

\section{Appropriate sanction}

Our subjects were asked to suggest, in their own views, the best measures that could help prevent and control church attacks in Nigeria. Again, the vocabularies of sanction or punishment respondents used are classified into two categories, namely: hypothetical-hypocritical pessimism and optimism as corroborated by Otu et al. (2018).

\section{Hypothetical and hypocritical pessimism}

We describe this to mean an expression of a bleak hope on the prospect of any sanction or sanctions effectively tackling church killings in Nigeria. Respondents are of the view that attacking churches will not come to an end, notwithstanding the sanction or sanctions in place. (see Otu et al. 2018:n.p.)

Some of their views and feelings are as expressed below.

A victim laments:

'No bros! Nobody fit stop church killings because some big people wey dey power dey support them as their people wey dey fight for their interest [Brother, no one can stop church attacks because quite a number of people who are in power support the attackers and see them as their brothers who are fighting to protect the interest of their religion and ethnic people].' (P4, 40 years old, interviewed on 04 September 2019)

This is in line with the view of Salawu (2010) who sees the attitude of government's negligence to be oppressive, discriminative and a major factor that causes attacks in churches.

A suspect explains the situation and predicament:

Anybody telling you say [that] we go [will] stop na lie [is rather daydreaming]. However, church attacks can only be reduced if community members see the herders as their brothers.' (P2, 47 years old, interviewed on 07 October 2019)

\section{Hypothetical and hypocritical optimism}

Optimism involves expressing positive hope that a particular action or inaction will yield positive value or outcome. It suggests keeping hope alive, even in the face of a gloomy circumstance. (Ajah et al. 2017; Otu et al. 2018:n.p.)

Below are typical hypothetical or hypocritical optimistic suggestions expressed by some of our respondents.

A victim, out of anger and frustration, says:

'I rather suggest imprisonment for the attackers. I think a 28-year imprisonment go dey ok [will be appropriate].' (P10, 31 years old, interviewed on 02 December 2019)

Another victim who has suffered much, opines:

'Me $[I]$ suggest life imprisonment, knowing very well that one day the person fit [may] be pardoned. But death ... no! no! no!' (P12, 37 years old, interviewed on 13 October 2019)

It is sad to know that little attention has been paid to sanctuary attacks and killings in Nigeria, even though criticisms have been made. After a recent killing of two Catholic priests and 27 worshipers in a local Catholic church in Benue State Nigeria, the Nigerian Senate summoned the president for questioning (Henry \& Peter 2018). The questioning did not, however, yield any measureable positive result for the security of churches in Nigeria. US president, Donald Trump, also called on Nigerian government to put an end to church attacks and killings in Nigeria (Egbegi et al. 2018; Olalekan et al. 2018). Thousands of Christians have also protested (Evelyn 2018), but none of these efforts has resulted in any positive step by government to ensure more security in churches and bring those who perpetrate these killings to justice.

\section{Conclusion and recommendations}

Contemporary Nigerian churches have continued to suffer from spiritual and economic development; it is a regrettable tale of contradictions. There is astronomic quest for power and material wealth by the attackers of churches, and a good number of churches have become grooming ground for attacks, which is worsened by government failure to protect 
life and property. In addition, there are the uncertainties associated with government policies. In view of the forgone anti-social cancerous situation, practical recommendations are brought to the fore:

1. The authors recommend the need for peace education. This is because peace education will help to foster tolerance and fraternity towards people from other religions. It will reduce the prejudice and aversion towards adherents of other religions.

2. We need understanding and tolerance. 'Understanding' does not mean that we have to agree. It helps us to foster tolerance. Through tolerance, we learn to see our differences, not as threats but as adding interest and richness to life. Tolerance is not only the resolution and respect towards beliefs, but also demands respect for the individuals who belong in the same society. Such a tolerance is one without border (Rahman \& Khambali 2013). Tolerance between different religions can only grow from the basic belief professed by the three monotheistic religions that 'there is only one God the Father of all, and we are all his children' (Rahman \& Khambali 2013).

3. Cooperation is another important factor that will help foster peace among religious groups. There is serious competition in our world today. It is worse in Nigeria. In the midst of scarcity and poverty, we need cooperation rather than unhealthy competition. This will make people work together rather than working against each other.

4. Leaders in Nigeria can achieve peace and defeat extremism by working together honestly and not for their personal aggrandisement.

5. Justice served - Armed violence cannot be stopped until the root cause of the problem is addressed. Lack of justice has caused bitter violence in Nigeria. For example, in many parts of Plateau State as elsewhere, we have seen people who were neighbours for decades rise up at a point in time to kill each other. Justice is needed to address issues of marginalisation, discrimination, domination and human rights abuses.

6. Finally, there is need to promote African traditional values, such as the sacredness of life, human respect and good human behaviour. These will help put an end to church killings in Nigeria and in other African countries.

\section{Acknowledgements}

The authors would like to thank Dr Ajah Julius Ogudu and Dr Ajah Leonard Ogbonna for their guiding comments and support during the data collection.

\section{Competing interests}

The authors declare that they have no financial or personal relationships that may have inappropriately influenced them in writing this research article.

\section{Authors' contributions}

E.O.A., C.O.O., D.O.O., B.O.A., O.S.O., C.D.O., A.C.O. and E.M.O. contributed to the conception and the drafting of the manuscript, gathering of data, analysis and interpretation of the data, critical revision of the manuscript, proofreading and the approval of the manuscript.

\section{Funding information}

This research received no specific grant from any funding agency in the public, commercial or not-for-profit sectors.

\section{Data availability}

Data sharing is not applicable to this article as no new data were created or analysed in the study.

\section{Disclaimer}

The views and opinions expressed in this article are those of the authors and do not necessarily reflect the official policy or position of any affiliated agency of the authors.

\section{References}

Achunike, H.C., 2008, 'Religious practices in Nigeria as source of social conflict', Journal of Liberal Studies 12(1\&2), 286-295.

Agbu, D.A., Musa, H. \& Zhema, S., 2020, 'Insurgency, armed herdsmen and instability in Nigeria: A search for the way forward', Global Journal of Arts, Humanities and Social Sciences 8(6), 63-81.

Ajah, B.O., 2018, 'Educational training of inmates in Awka and Abakaliki prisons, Nigeria', International Journal of Criminal Justice Sciences 13(2), 299-305.

Ajah, B.O. \& Nweke, J.O., 2017, 'Prison facilities and the welfare of inmates in Nigeria: A study of Abakaliki and Awka prisons', World Applied Sciences Journal 35(3), 361-369.

Ajah, B.O., Nwokeoma, B.N. \& Okpan, S.O., 2017, 'Socio-economic implication of kidnapping and hostage taking in Southern Nigeria', Journal of Law and Judicial System 1(1), 51-59.

Bakeni, J., 2019, 'Attacks on Nigeria's Christians growing', Zenit, viewed 03 March 2020, from https://zenit.org/articles/attacks-on-nigerias-christians-growing/.

Beven, K., 2006, 'A manifesto for the equifinality thesis', Journal of Hydrology 320(1-2), 18-36. https://doi.org/10.1016/j.jhydrol.2005.07.007

Chris, O., 2019, 'Herdsmen kill parishioners; seek death of businessman Victor Nwankwo', Vanguard, viewed 02 December 2019, from https://www.vanguardngr. com/2019/02/herdsmen-kill-parishioners-seek-death-of-businessman-victornwankwo/.

Cook, D., 2012, 'Boko Haram escalates attacks on Christians in Northern Nigeria', Combating Terrorism Center, viewed 07 May 2019, from https://ctc.usma.edu/ boko-haram-escalates-attacks-on-christians-in-northern-nigeria/.

Daniel, S., 2020a, 'Boko Haram targeting Christians to trigger religious war Mohammed', Vanquard, viewed on 10 December 2020, from https://www. vanguardngr.com/2020/02/boko-haram-targeting-christians-to-trigger-religiouswar-mohammed/.

Daniel, S., 2020b, 'Why Boko Haram/ISWAP attack churches - Lai Mohammed', Vanguard, viewed on 13 December 2020 from, https://www.vanguardngr. com/2020/02/why-boko-haram-iswap-attack-christians-churches-lai-mohammed/.

Egbegi, F.R., Ajah, B.O. \& Ogbonnaya, C., 2018, 'Combating Boko Haram insurgency through a superior ideology: The role of the federal government', European Journal of Political Science Studies 1(2), 13-22.

Ele, C., 2001, 'Islamic triumphalism: A threat to Christian presence in Nigeria', Shepherd Magazine, 1(2), August 19th, pp. 15-16.

Ele, C.O., 2018, 'Islamization of Nigeria: Implications for sustainable peace', International Journal of Social Sciences and English Literature 2(1), 13-19. https:// doi.org/10.20448/journal.527.2018.21.13.19

Emeh, O., 2011, 'Analysing Nigeria's current crime surge', Vanguard, viewed 27 January 2019, from https://www.vanguardngr.com/2011/01/analysing-nigeria\%E2\%80\%99scurrent-crime-surge/

Essays UK, 2013, Statistical analysis on crime rate in Nigeria, viewed 03 April 2020, from https://www.ukessays.com/essays/statistics/statistical-analysis-of-crime-innigeria. php?vref=1.

Evelyn, O., 2018, 'Killings: Christians protest in Abuja', Premium Times, viewed 27 June 2020, from https://www.premiumtimesng.com/news/more-news/269355-killingschristians-protest-in-abuja.html.

Henry, U. \& Peter, D., 2018, 'Killings: Senate summons Buhari as herdsmen attack another Benue church', Vanguard, April, 23rd, p. 48.

Jamela, A., 2018, 'Fulani herdsmen in Nigeria blamed for attack on church', Aljazeera viewed 02 February 2020, from https://www.aljazeera.com/news/2018/05/ fulani-herdsmen-nigeria-blamed-attack-church-180507085827448.html. 
Longii, A.D., 2015, 'The impact of Boko Haram on church and society in Nigeria', Grin, viewed 02 July 2020, from https://www.grin.com/document/388005.

Mamah, E., Ndujihe, C., Nkwopara, C. \& Ozor, C., 2016, 'Bloodbath in Enugu as Fulani herdsmen kill 40', Vanguard, viewed n.d., from https://www.vanguardngr. com/2016/04/bloodbath-enugu-fulani-herdsmen-kill-40/.

Morning Star News, 2019, Local Muslims suspected in killing of Christians after Sunday worship in Jos, Nigeria, viewed 11 December 2020, from https://www. christianheadlines.com/blog/local-muslims-suspected-in-killing-of-christiansafter-sunday-worship-in-jos-nigeria.html.

Nnam, M.U., Ajah, B.O., Arua, C.C., Okechukwu, G. \& Okorie, C.O., 2019, 'The wa must be sustained: An integrated theoretical perspective of the Cyberspace-Boko Haram Terrorism Nexus in Nigeria', International Journal of Cyber Criminology 13(2), 379-395.

Nweke, J.O. \& Ajah, B.O., 2017, 'Challenges facing vocational training of prison inmates in Nigeria: A study of Abakaliki and Awka prisons', International Journal of Sciences and Research 73(5), 33-48. https://doi.org/10.21506/j.ponte.2017.5.4

Nwune, F.R., Chikwelu, E., Ajah, B.O. \& Obiefuna, C.E., 2018, 'Correctional programmes within the prison community: The views and perception of inmates and staff in Anambra State Prisons, Nigeria', Developing Country Studies 8(6), 1-7.

Nzwili, F., 2019, 'Deadly violence linked to Fulani herdsmen take toll on Nigerian Christians', The Catholic World Report, viewed 12 December 2020, from https:// www.catholicworldreport.com/2019/08/27/deadly-violence-linked-to-fulaniherdsmen-take-toll-on-nigerian-christians/.

Okiro, M., 2005, Proliferation of illegal arms and ethno-religious violence in Nigeria, CLEEN Foundation, Lagos.

Okpa, J.T., Ajah, B.O. \& Okunola, R.A., 2018, 'Religious fundamentalism and sustainable development in Nigeria: Understanding the intricacies', Journal of Religion and Theology 2(2), 12-18.

Olalekan, A., Olokor, F., Hanafi, A. \& Charles, J., 2018, 'Killing of Christians in Nigeria must stop, says Trump', Punch Newspaper, May 1st, p. 56.

Otu, S.E., Nnam, M.U. \& Uduka, U.K., 2018, 'Voices from behind the bars: Kidnappers' natural self-accounting views, perceptions, and feelings on kidnapping in the South-eastern states of Nigeria', Journal of Forensic Psychology Research and Practice 18(3), 254-279. https://doi.org/10.1080/24732850.2018.1471649

Pogrebin, M.R., Poole, E.D. \& Martinez, A., 2012, 'Accounts of professional misdeeds: The sexual exploitation of clients by psychotherapists', in M.R. Pogrebin (ed.) About criminals: A view of the offenders' world, 2nd edn., pp. 94-104, SAGE Publications, Inc., s.l.

Rahman, N.F.A. \& Khambali, K.M., 2013, 'Religious tolerance in Malaysia; problems and challenges', International Journal of Islamic Thought 3, 81-91. https://doi. org/10.24035/ijit.03.2013.007
Refugee Documentation Centre, 2018, Researched and compiled by the Refugee Documentation Centre of Ireland on 12 February 2018, viewed n.d., from https:// www.ecoi.net/en/file/local/1430784/1788_1524739298_1202.pdf.

Salawu, B., 2010, 'Ethno-religious conflicts in Nigeria: Causal analysis and proposals for new management strategies', European Journal of Social Sciences 13(3), 345-353.

Suleiman, K.O., 2016, 'Religious violence in contemporary Nigeria: Implications and options for peace and stability order', Journal for the Study of Religion 29(1), 85-103.

Sykes, G. \& Matza, D., 1957, 'Techniques of neutralisation: A theory of delinquency', American Sociological Review 22(6), 644-670.

The Guardian, 2020, US adds Nigeria to blacklist on religious freedom, viewed 10 December 2020, from https://guardian.ng/news/us-adds-nigeria-to-blacklist-onreligious-freedom/.

Ugwuoke, C.O., Ajah, B.O. \& Onyejegbu, C.D., 2020, 'Developing patterns of violent crimes in Nigerian democratic transitions', Aggression and Violent Behavior 53 , 1-8. https://doi.org/10.1016/j.avb.2020.101457

Ukwayi, J.K. \& Okpa, J.T., 2017, 'The effect of electoral and economic crimes on sustainable development in Cross River State, Nigeria', International Journal of Social Science Research 5(2), 32-42. https://doi.org/10.5296/ijssr.v5i2.11693

Ukwayi, J.K., Okpa, J.T. \& Dike, E., 2018, 'Ethnic and religious conflict in Jos, Plateau State, Nigeria: A dangerous threat to human existence and business activities', Research on Humanities and Social Sciences 8(8), 31-37.

Umeagbalasi, E., 2020, 'Nigeria is a killing field of defenseless Christians', Genocide Watch, viewed 12 December 2020, from https://www.genocidewatch.com/ single-post/2020/04/13/nigeria-is-a-killing-field-of-defenseless-christians.

Union of Catholic Asian News, 2020, 620 Christians killed in Nigeria this year, viewed 09 December 2020, from www.google.com/amp/s/www.ucanews.com/amp/620christians-killed-in-nigeria-this-year/88111.

Von Bertalanffy, L., 1968, 'General system theory: Foundations, development', George Braziller, New York, NY.

Wantu, J., 2018, 'Suspected herdsmen kill two Catholic priests, 17 others', Guardian viewed 03 December 2019, from https://guardian.ng/news/suspected-herdsmenkill-two-catholic-priests-17-others/.

World Watch Monitor, 2018, Nigeria: Pastor and three sons burned alive among at least 20 killed in latest Plateau massacre, viewed 09 December 2020, from https://www.worldwatchmonitor.org/2018/09/nigeria-pastor-and-three-sonsburned-alive-among-at-least-20-killed-in-latest-plateau-massacre/.

Zenn, J., 2017, 'Demystifying Al-Qaida in Nigeria: Cases from Boko Haram's founding, launch of Jihad and suicide bombings', Perspective on Terrorism 11(6), 173-189. 